\title{
Integrating Floodplain and Stormwater Management : Historical Perspective, Concepts and Case Study
}

\author{
Gilles Rivard, Stéphane Bélanger and Pierre Dupuis
}

Floodplain management and stormwater management have many similarities and should ideally be analyzed in an integrated way for effective planning. Historically, these two planning activities have evolved as separate tasks and are often carried out in an isolated way, the latter being most often associated directly with a local government, whereas the former is usually the responsibility (and financed by) a provincial or federal ministry. When some problems appear at the municipal level and part of the solution is tied to a regional and floodplain management plan, this artificial separation can sometimes prevent optimal solutions. Also, when land development in the floodplain is considered, specific and sometimes innovative solutions have to be implemented in order to be able to continue the urban development without affecting the level of protection.

After a general discussion of historical developments in North America and specifically in the Province of Québec, concepts and types of interactions between the two planning activities are presented. A case study for the City of Saint-Constant, on the south shore of the St-Lawrence River near Montréal, is then given to highlight specific stormwater management approaches. The approaches protect existing areas or enable land development in the floodplain, taking into account the entire watershed hydrologic response. The interface problems/opportunities between floodplain and stormwater management are also presented and discussed.

Rivard, G., S. Belanger and P. Dupuis. 2003. "Integrating Floodplain and Stormwater Management : Historical Perspective, Concepts and Case Study." Journal of Water Management Modeling R215-01. doi: 10.14796/JWMM.R215-01.

(C) CHI 2003 www.chijournal.org ISSN: 2292-6062 (Formerly in Practical Modeling of Urban Water Systems. ISBN: 0-9683681-7-4) 


\subsection{Introduction - Historical Development}

Stormwater and floodplain management are closely inter-related, with numerous interfaces with each other that are often poorly reflected in existing institutional arrangements. Some of these interface problems are associated with the historical development of both planning activities and also the type and scale of floods that each should typically address. A brief summary of the historical development of floodplain management in the United States and in Canada is given, with additional emphasis on the approaches used in the Province of Québec.

Figure 1.1 provides the basic components usually involved in floodplain analysis, the floodway and the fringe area. Typically, floodplain management addresses areas flooded at least once in 100 years, which is often used as a Base Flood. Studies for the FEMA (Federal Emergency Management Agency) in the United States also include 10-y, 50-y and 500-y frequencies. The flood-plain boundaries are delineated for the 100-y and 500-y floods.

The narrower area called the floodway includes the channel of the stream and the adjacent area which is defined using different criteria. In the United States, the floodway is the designated portion of the $100 \mathrm{y}$ floodplain needed to convey the 100-y discharge without cumulatively increasing the water surface elevation above a designated height when compared to the base water surface elevation (which could be defined as the elevation to which a body of water could be expected to rise during a $100-\mathrm{y}$ flood event). Normally, a height of $0.3 \mathrm{~m}(1 \mathrm{ft})$ is the maximum allowable rise criterion. The purpose of designating the floodway is to prevent fill, structures or other obstructions from being placed too close to the channel without extensive analysis and mitigation measures. Hydraulically, the floodway must have sufficient capacity to convey the existing 100-year peak flow rate at a water surface profile which is $0.3 \mathrm{~m}$ higher than the existing conditions $100-y$ water surface profile. The fringe area extends to the outer limit boundaries of the $100-y$ flood plain delineation.

In Canada, the federal Flood Damage Reduction Program mentions two types of flood-risk zones: high-velocity (which can be inundated by a flood having a return period of $20 \mathrm{y}$ or less) and low-velocity (which can be inundated by a flood having a return period between 20 and $100 \mathrm{y}$ ). The elevations used to identify the boundaries of these zones are those calculated for the $20-y$ and 100-y floods (NRCC, . 1990). These elevations and designated zones are used in municipal regulations governing construction and renovation; they are also used as references by governments when applying bilateral agreements stemming from the Flood Damage Reduction Program. 


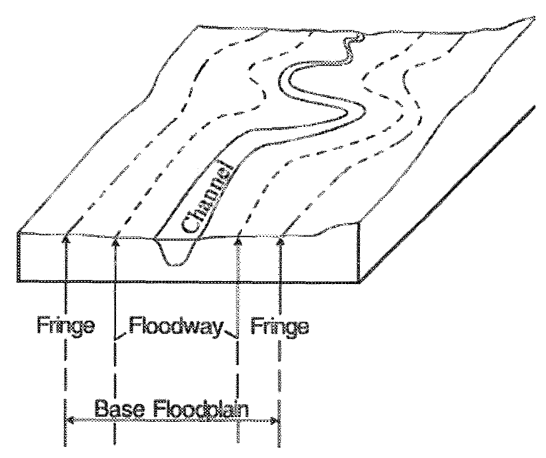

Figure 1.1 Elements of a floodplain.

Historically, approaches to dealing with floods in the United States changed dramatically during the 20th century (Wright, 2000; Walesh, 1989). The federal government became concerned with flooding on a national level following the disastrous Mississippi inundations of 1927, the Ohio River flood of 1937 and similar events on other large rivers (Whipple et al., 1983). A national flood control program was then initiated by the Corps of Engineers, devoted mainly to large rivers. During the 1950 s, Gilbert White initiated studies that led to major changes in national flood control policy. White found that despite expenditure of many billions of dollars, the national total of flood damage was not being reduced, but was actually increasing due to the continued tendency to occupy floodplains. He instead advocated "adjusting human occupancy to the floodplain environment so as to utilize most effectively the natural resources of the floodplain, and at the same time, of applying feasible and practicable measures for minimizing the detrimental impacts of floods" (Wright, 2000). It is widely accepted that Gilbert F. White's seminal study stimulated the interest and set the course for the emergence and evolution, in ensuing decades, of broader approaches to flood problems. However, as pointed out in Whipple et al. (1983), these initial programs were not designed to deal with increasing floods in urbanizing areas, which were just beginning to be better understood at that time.

As defined by the Flood Control Acts of 1928 and 1936 (Wright, 2000), the role of government agencies was to build massive flood control structures to control the great rivers, protect coastal areas and prevent flash flooding. Until the 1960s, such structural flood control projects were seen as the primary way 
to reduce flood losses. In 1968, the National Flood Insurance Program (NFIP) was established. As history would reveal, the NFIP would ultimately have a profound impact in two important areas: first, by accelerating the identification of floodprone areas on maps, and second, in providing incentives for state and local units of government to enact measures to regulate development in these identified areas. The 1970s and the 1980s were therefore the decades during which floodplain mapping and land use regulation were initiated. Today, as pointed out in Wright (2000), the federal government remains a major player in the overall floodplain management process, both from a financial point of view and a technical one. Even if floodplain management is implemented at the local government level, there is considerable federal influence in terms of minimum requirements and criteria. The strategy has as multiple objectives to protect or remove existing development from floodplain, but also to capitalize on recreational, scenic, ecologic and cultural values of floodplains.

In Canada, the Canada Water Act, passed in 1970, made possible the participation of the federal government in water resources management programs and water quality programs with one or more of the provinces. In that context and following the severe inundations of 1974 and 1976, the federal government established in 1975 the Flood Damage Reduction Program. In the Province of Québec, this program has been established by the signature of a Canada-Québec agreement and has since then been modified twice. These agreements are:

- 1976 A federal-provincial agreement on flood risk mapping applied to flood damage reduction.

- 1987 A Canada-Québec agreement on mapping and floodplain protection.

- 1994 A Canada-Québec agreement on mapping and floodplain protection, and sustainable water resources development.

The 1976 agreement included a flood damage reduction policy and an agreement on flood risk mapping. Under this agreement, both levels of government, through their departments and agencies, undertook to:

- avoid building or in any way subsidize the building of structures in strong current areas (0-20-y). In the weak current area (20$100-y)$, these same agencies can only allow the building of, or provide financial assistance for, structures that meet effective floodproofing standards;

- encourage municipal authorities to impose restrictions, as required, to prohibit or make subject to floodproofing measures any future structures located in designated flood-risk areas; and 
- make ineligible for disaster assistance any construction undertaken after the official designation of the flood-risk area.

The 1987 agreement goes on to identify flood-risk zones and their geographical area. Also, it aims to jointly establish an intervention policy to reduce damages within each government's field of jurisdiction.

The 1994 agreement has the same main objectives as the 1987 agreement, with the exception of a new item about special studies on sustainable water resources development and, more specifically, on its management at the basin scale. In March 1997, the agreement ended regarding flood area identification. For the Province of Québec, 550 flooding maps were produced for about 60 streams and 250 municipalities, covering about $1100 \mathrm{~km}$ of streams.

However, exceptional floods occurred in the region of Saguenay in July 1996, which resulted in $350 \mathrm{M} \mathrm{C} \$$ in damages and significant loss of property and of river banks by erosion. Entire areas located in floodplains were literally wiped out and many streams were totally reconfigured by the floods. Figure 1.2 shows a view of some of the damages produced by the significant and extreme amount of rainfall for the region $(152 \mathrm{~mm}$ in $24 \mathrm{~h}$ and $231 \mathrm{~mm}$ in $48 \mathrm{~h}$ for an area of $5000 \mathrm{~km}^{2}$ ). Following these extreme events, which served as an alarm for the Ministry of Environment in Québec and politicians, a new program of floodplain delineation was put in place in 1998, for a period of five years.

According to the policy for bank protection and floodplain revised by the Ministry of Environment in Québec following the 1996 events, floodplain management was integrated into zoning and land use regulations and managed at the County level. No new buildings are permitted in the floodway (defined with the 20-y flood discharge) and buildings are allowed in the flood fringe with flood proofing and demonstration of adequate protection for future conditions.

What is evident from this brief historical review of floodplain management is that its development has always been in reaction to extreme events and to the high costs involved in resulting damages. This is consistent with what Walesh (1989) very appropriately called the hydroillogical cycle: flood - panic - studies - procrastination. The typical technical literature associated with floodplain management is also most often voiced in a restrictive tone, stating what is not permitted instead of giving detailed technical advice in a pro-active perspective. Surely, this approach is easier to manage from an institutional point of view; in practical cases, however, it may not be an optimal one.

On the other hand, stormwater management has been closely associated with urbanization and its importance was more clearly seen in the 1960s and beginning of the 1970s, when it became obvious that the development of urban areas could have a significant impact on the local flood events. Probably 


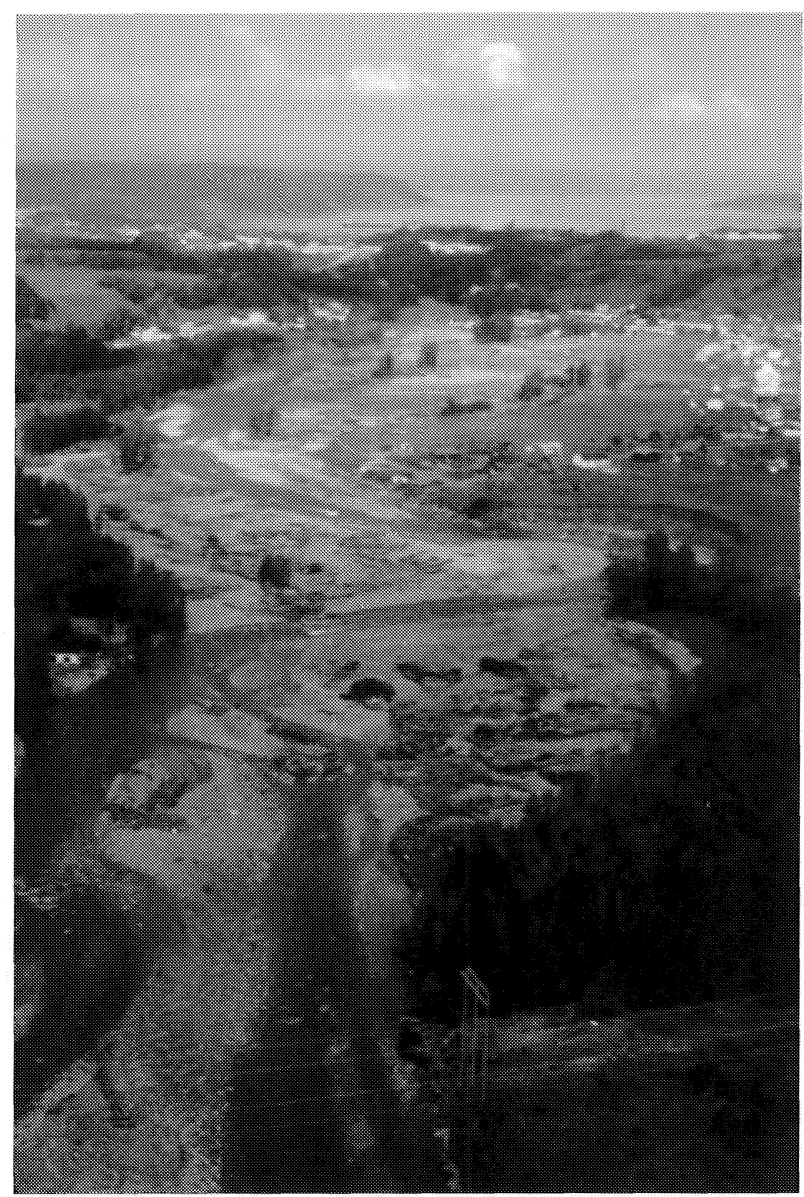

Figure 1.2 Part of the damages caused by the 1996 flood in Saguenay, Québec (Brooks and Lawrence, 1998).

because the problems appear at a low scale and usually produce localized damages that are less visible and important in scope, development of stormwater management was essentially left to localities and developers. Although it seems appropriate to analyze stormwater and floodplain management in an integrated way, the interactions between the two are in fact seldom discussed together in the literature. The following section first discusses the similarities and differences between the two, which provide a framework to some integrated strategies discussed later. 


\subsection{Similarities and Differences between Floodplain and Stormwater Management}

Walesh (1989) and Whipple et al. (1983) have discussed the similarities and differences that exist between floodplain and stormwater management. Basically, the distinctions seem to be more matters of scale and funding than of engineering substance, but the two activities have interfaces that are poorly reflected in existing institutional arrangements, either for planning or for financing. Table 1.1 provides an overview of these similarities and differences.

Table 1.1 Similarities and differences between floodplain management and stormwater management (adapted from Walesh, 1989).

\begin{tabular}{|c|c|}
\hline Similarities & Differences \\
\hline $\begin{array}{l}\text { Objectives (life, safety and damages } \\
\text { reduction/prevention) }\end{array}$ & $\begin{array}{l}\text { Level of analysis (small versus large } \\
\text { drainage areas) }\end{array}$ \\
\hline Public interest intense but brief and infrequent & Intramunicipal versus intermunicipal level \\
\hline Similar structural and non-structural measures & Regulations / Funding \\
\hline $\begin{array}{l}\text { Identical hydrologic/hydraulic processes and } \\
\text { engineering tools }\end{array}$ & $\begin{array}{l}\text { Watershed approach (floodplain } \\
\text { management tends to be less integrated) }\end{array}$ \\
\hline Parts of the same watershed & $\begin{array}{l}\text { Quality concerns (usually not considered in } \\
\text { floodplain management) }\end{array}$ \\
\hline \multirow[t]{2}{*}{ Runoff control outside the floodplain } & $\begin{array}{l}\text { Level of protection (100-year typically } \\
\text { minimum for floodplain management; } \\
\text { usually less for local drainage systems, } \\
\text { where the } 100 \text {-year is typically not } \\
\text { explicitly analyzed) }\end{array}$ \\
\hline & $\begin{array}{l}\text { Considerations of future conditions (not } \\
\text { always explicitly analyzed in floodplain } \\
\text { studies) }\end{array}$ \\
\hline
\end{tabular}

Some of the differences and the interfaces can provide a basis for integrated strategies. The most important element is to use detailed modeling in order to be able to appropriately define the global hydrologic/hydraulic behavior of the entire system, including local drainage systems and the water receiving bodies. As the main rivers and channels receiving the storm runoff from local drainage systems have typically a much larger total drainage area, their hydrologic response and timing will often be significantly different from the local systems. Opportunities will therefore appear to manage each part (the floodplain and the local drainage systems) in such a way as to minimize the consequences in the overall response. The analysis at a large scale will also make it possible to consider the effect of urbanization in an integrated way, which could in some cases indicate that no control is necessary at a local level. Finally, 
there is no logical reason to manage the floodplain with the 100 -y event and to design the adjacent local system with, for example, a 5-y event, without explicitly analyzing the system with a 100 -y event. The overall system should ideally be designed at a 100-y level, ensuring that every building, regardless of its location, is protected using uniform criteria. These basic elements are further discussed in the following section.

\subsection{Strategies and Approaches for Integration}

Although it appears to make sense to totally prohibit development in the floodplain, this drastic approach is often not possible for different reasons, and special measures to reduce flood damages must be implemented for specific cases, for example:

- the project site is not itself in a flood hazard area, but is where development might increase flood levels elsewhere;

- existing buildings are located in a fringe area that is subject to only mild flooding;

- buildings can be cost-effectively floodproofed to achieve an acceptable level of safety;

- the project includes existing buildings that, due to historical or economic significance, must remain in a flood-prone area; and

- the only logical and practical areas for new development in a locality are in the fringe area of a floodplain.

In many of these practical applications, the development of optimal solutions must be based on an appropriate integration of floodplain and stormwater measures. Usually, these measures can be classified as structural and non-structural, and Table 1.2 summarizes the most frequent techniques for each activity. In general, structural measures tend to be more applicable to existing areas, whereas non-structural measures tend to be more appropriate for undeveloped areas.

These different measures have been discussed individually or as a group in many publications; the emphasis here is on interactions between measures for stormwater and floodplain management. Also, the quality aspect is not included in the discussion, although more recent developments in both activities point out the importance of properly addressing this element.

The different strategies available to manage activities in the floodplain can also be divided into four categories, as defined in Table 1.3. Each strategy is supported by an array of tools and many of these tools can be used in more than 
Table 1.2 Typical measures for floodplain and stormwater management.

\begin{tabular}{lll}
\hline Type of measures & Floodplain Management & Stormwater Management \\
\hline Structural & Dams & Inlet control \\
& Dikes & Underground storage \\
& Levees & Surface storage on streets, parking lots \\
& Channel improvements & Ponds \\
& Flow regulation (diversion, & Infiltration systems \\
& storage) & Sump pumps \\
& Culvertbridge alteration or & \\
& replacement & \\
Non-Structural & Land-use regulation & Land-use regulation \\
& Floodplain Regulations & Stormwater Manual \\
& Flood insurance & Stormwater By-laws \\
& Floodproofing & Inspection/Maintenance programs \\
& Acquisition, relocation or & Public education \\
& demolition of existing & \\
buildings & Flood warning systems & \\
& Emergency action plans & \\
\hline
\end{tabular}

Table 1.3 General Strategies for Floodplain Management (adapted from French and Associates, FEMA, 1998).

\begin{tabular}{ll}
\hline \multicolumn{1}{c}{ Strategies } & \multicolumn{1}{c}{ Applicable measures } \\
\hline Modify human susceptibility to flood damage & Regulating (zoning) \\
& Policies for existing or new development \\
& Land acquisition \\
& Floodproofing \\
& Preparing people and property \\
& Restoring / preserving \\
& Information / Education \\
Modify the impact of flooding & Flood emergency measures \\
& Financial assistance \\
& Post-flood recovery plans \\
& Structures \\
Modify flooding itself & Alteration of channels \\
& Diverting flows \\
& Floodproofing \\
& Storage \\
Runoff control outside the floodplain \\
Zoserve / restore natural resources & Zoning \\
& Development and redevelopment policies \\
& Land acquisition \\
& Tax adjustments for financial initiative \\
\hline
\end{tabular}


one strategy; in most cases, a combination of these tools is needed to reduce risks and protect natural resources and functions. This general context is used to present specific elements of interaction between stormwater and floodplain management that could be used to define solutions.

\subsubsection{Timing and Types of Floods}

As pointed out before, the hydrologic behavior of the main receiving channel and the local drainage systems are often significantly different. Typically, the receiving water body will be a river draining a much larger drainage basin than individual areas of urban development and the peak discharges for both areas will likely be in totally different phases (the hydrologic response of the smaller urban system being much faster and the peak discharge being created by different causative events). The following elements could therefore be considered for an integrated approach:

- Especially for a watershed draining a large rural area and for which the main channel enters the urban area located in the lower portion of the basin, the timing of the global basin versus the local urban systems must be analyzed with a global model. In some cases, this analysis may reveal that, for purely flooding aspects in the main river, no control is necessary for the local systems (control for erosion may however be necessary). For example, if the hydrologic response of the large basin is $12 \mathrm{~h}$ and that of the local system is less than $30 \mathrm{~min}$, it can be demonstrated that the impact of flow control on the local system is negligible. In fact, aggressive control implemented for the local system might produce the opposite result (i.e. increase of peak discharge of the main channel) if the detention for a long period produces a delayed hydrologic response for the small urban systems.

- It is important to distinguish the meteorological events that should be used for the design and their time of occurrence. In most parts of the Province of Québec, the main driving event for critical peak flows for many rivers is snow melting with rainfall at spring time. Typically, this is characterized by a large volume of water, a slow hydrologic response and low rainfall intensity. Usually, the snow will melt first on urban areas and the low intensity of the rainfall events observed at spring will not be critical for small urban drainage basin. So the overall system, including the main river and the local drainage system, must be designed for two different 
conditions: at spring time when the water levels in the river will be high but the volume of runoff from the urban areas low and for summer thunderstorms, which are the usual rainfall events used to design the conduits system.

\subsubsection{Street and Local Storage}

The available storage on the street is not traditionally considered in drainage system design but it can be used both for existing areas and new development to provide a significant amount of volume. Taking into account this volume could give a cost-effective solution to retrofit existing areas with flooding problems and can also help reduce end-of-pipe storage for new development. As the land located in the flood fringe is usually relatively flat, there is an interesting volume that could be stored on the street surface without too much inconvenience (typically from 10 to $75 \mathrm{~m}^{3}$ for each low point on a street $9 \mathrm{~m}$ wide, depending on the longitudinal slope (Rivard, 1998)).

For existing areas with flood problems, the streets can be used as temporary storage, as demonstrated years ago by Walesh in Stokie, Illinois. This case study has been recently re-visited in detail in an EPA publication (Walesh, 1999). The concept can be used also for new developments with detailed analysis. For example, Rivard and Dupuis (1999) have analyzed for the Montréal area typical sub-basins for residential areas draining towards a low point, using a historical rainfall series of $52 \mathrm{y}$. They concluded that the following cases produced acceptable flow depths on the street surface at the low points (lower than $150 \mathrm{~mm}$, the usual curb height):

- sub-basin drainage area from 0 to $1 \mathrm{ha}: 40 \mathrm{~L} / \mathrm{s}$ limiting discharge at low point;

- sub-basin drainage area from 1 to $2 \mathrm{ha}: 60 \mathrm{~L} / \mathrm{s}$ limiting discharge at low point; and

- sub-basin drainage area from 2 to $3 \mathrm{ha}: 80 \mathrm{~L} / \mathrm{s}$ limiting discharge at low point.

Using the 52 y historical series, Figure 1.3 provides an example of the impact of providing street surface storage. In this case, a 1.6 ha sub-basin drains towards a low point, which is controlled by inlet restrictors with a limiting discharge of $40 \mathrm{~L} / \mathrm{s}$ (with two inlets at the low point, which gives $20 \mathrm{~L} / \mathrm{s} / \mathrm{inlet}$ ). The overall control for the case presented in Figure 1.3 is limited at $100 \mathrm{~L} / \mathrm{s} / \mathrm{ha}$ (the remaining discharge being intercepted by inlets located on continuous slope toward the low point). For the Montréal area, this value of specific discharge corresponds to a return period between 5 and 10 -y after development with $30 \%$ 


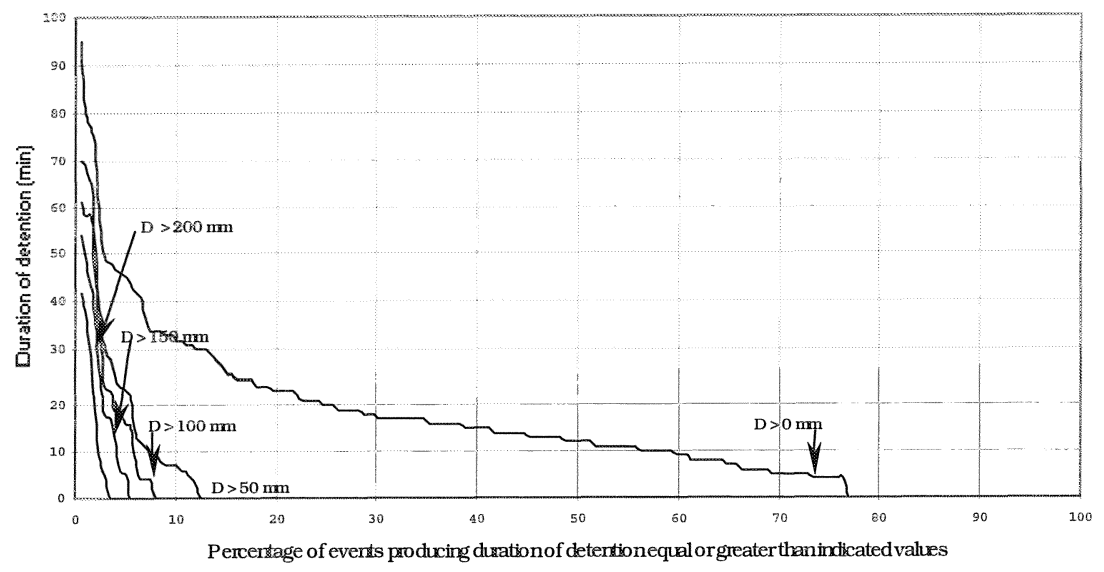

Figure 1.3. Analysis of surface retention on the street surface (at a low point) for a residential sub-basin ( $1.6 \mathrm{ha}, 30 \%$ imperviousness), a maximum inflow of $40 \mathrm{~L} / \mathrm{s}$ at the low point and a total specific discharge of $100 \mathrm{~L} / \mathrm{s} / \mathrm{ha}$.

imperviousness. In other words, this analysis shows that, even for extreme rainfall events, it is feasible to restrict the inflows to these values and to store the differences on the street at the low points.

\subsubsection{Piezometric Lines and Design Approach}

Another element that is essential to consider for the design of stormwater drainage systems in a floodplain area is the influence of water levels in the receiving channel on the overall piezometric line. As pointed out before, two cases should be analyzed. First, at spring time, when the water levels in the river are at their highest, an appropriate design storm is used in the conduits (which should be of less intensity than the usual storms used to size the pipes). Environment Canada produces specific Intensity-Duration-Frequency (IDF) curves for snowmelt and rainfall; these quantities of precipitation can then be used with an appropriate mass curve (like a 24-h SCS type II). Secondly, the normal or average water levels, that should be observed during the summer, are used, with the more intense design rainfall event. It is therefore appropriate to use design events that reflect the overall system response at different times of the year (high water levels at the downstream boundaries with lower rainfall intensity at spring time and lower water levels in the river with higher intensity rainfall during summer thunderstorms) and to determine the piezometric line accordingly. A joint probability is therefore more logical for the analysis. 


\subsubsection{Ponds with Appropriate Design Criteria}

The same general features for the interface between floodplain and stormwater management should also be used to design end-of-pipe ponds, taking into consideration, for example the timing of discharges and the existence of street ponding. As the volume of runoff from the urban areas at spring time is generally less important, it could be feasible to store the complete volume of a given recurrence interval as long as the water levels in the river are high (which lasts typically from 1 to 2 weeks). A comparative analysis could then be made using as a design criterion for the pond volume the usual design storm, but with a given amount of water leaving the pond as the water levels in the river will be lower. Routing calculations will then indicate the more critical situation. Taking into consideration the storage at low points will also help reduce the volume needed at the end-of-pipe facility.

\subsection{Case Study}

Many of the different elements discussed have been put into practice for the City of Saint-Constant, located on the south shore of the Saint Lawrence River in the Montréal area. As can be seen in Figure 1.4, the urban areas of the City are located close to the shore of the Saint Lawrence River and the main channels used as outlets for the drainage systems drain relatively large rural areas before entering the urbanized areas. The two rivers each drain areas of about 4500 ha and combine downstream of Saint-Constant before reaching the Saint Lawrence River. As a basis for comparison, the area for the urbanized part of SaintConstant is about $325 \mathrm{ha}$, and the development has taken place close to the two rivers, resulting in a rapid hydrologic response at the outlets.

Two large flood events were observed in 1996 and 1997, and the significant damages prompted the City to undertake a large-scale study to analyze the events and recommend remedial measures. The 1996 event was in November, with a long rainfall generating record water levels in the main rivers (125 mm of rainfall in about $29 \mathrm{~h}$; as a comparison, the quantity of rainfall for a $24 \mathrm{~h}$ period, as given by the IDF curves, was $93 \mathrm{~mm}$ ). Figure 1.5 shows a view of part of one of the flooded areas, where the high water levels in the main rivers backflowed in the smaller lateral ditches and creek.

As there was no floodplain delineation for the two main rivers, a global modeling effort was then carried out with the SWMHYMO software to obtain the discharges for different return periods $(2,20$ and 100-y to follow the 


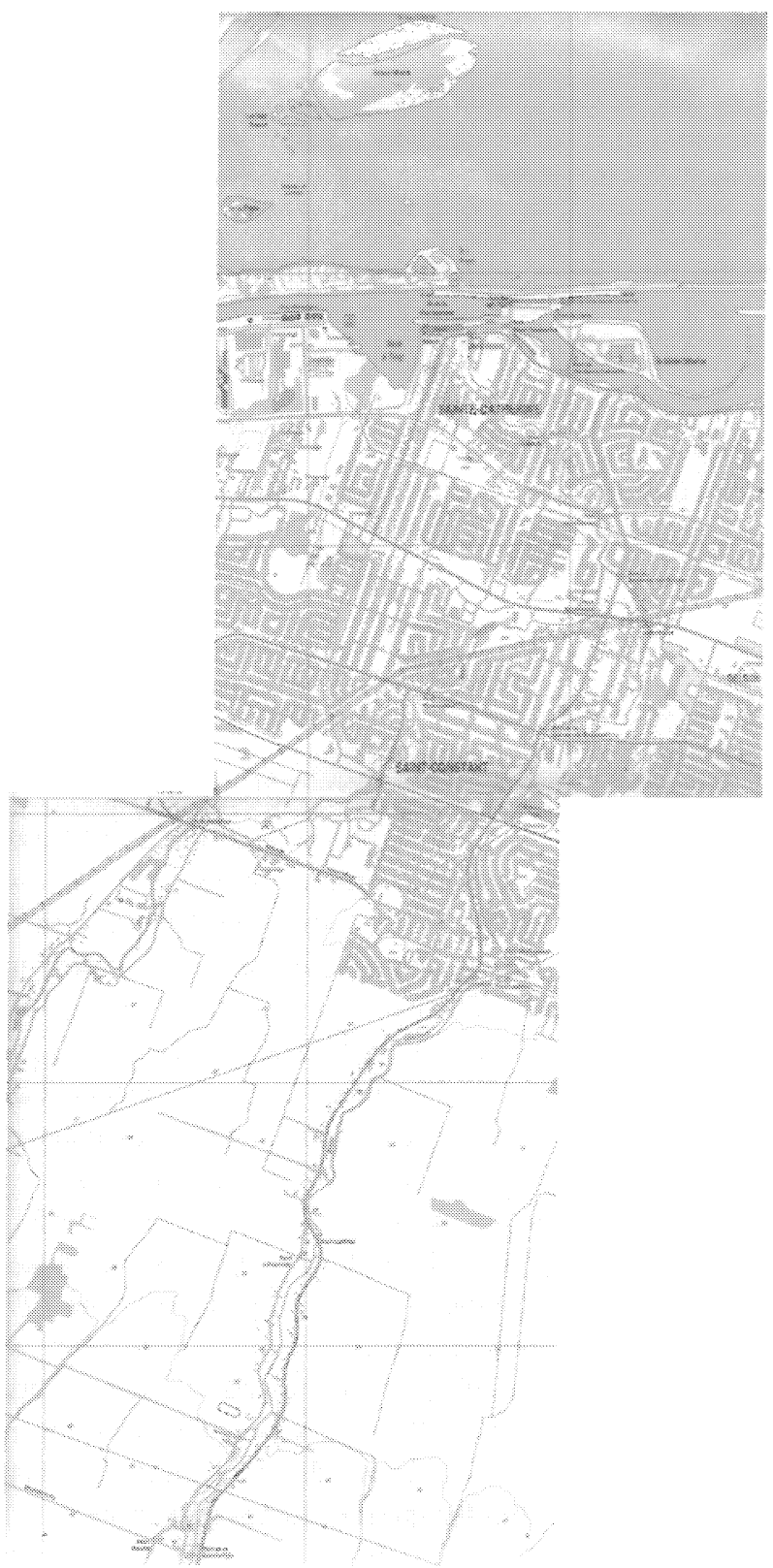

Figure 1.4 General location, City of Saint-Constant. 


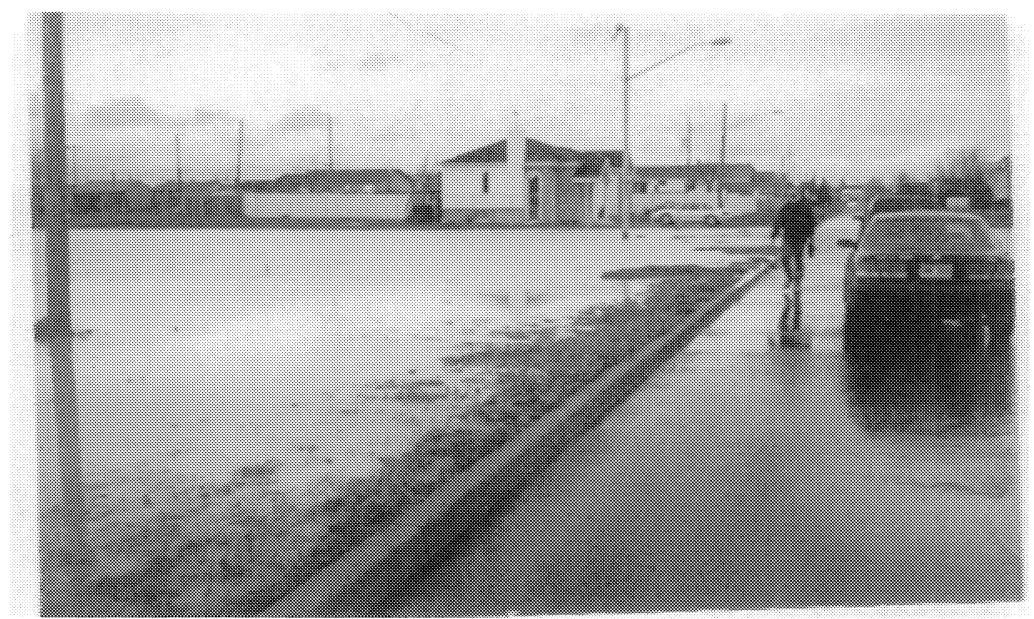

Figure 1.5 Flood of 1996, with the ditch connected to the main river overflowing.

provincial guidelines) and HEC-RAS (River Analysis System) to obtain corresponding water levels. The modeling effort was based on recorded discharges and water levels that enabled a calibration.

Using the floodplain delineation, the analysis then proceeded to define solutions to specific problems in existing areas and also for future developments. Even if the 1996 and 1997 events made the City representatives aware of the necessity to restrict and control new urbanization, some of the new developments were to take place in the flood fringe, and it was therefore important to implement solutions that would not produce high flooding risks for these areas.

\subsubsection{Existing Areas}

Referring to Table 1.3, most of the available measures were used to protect existing areas from future flooding, ranging from information and education programs and regulations through large scale structural measures. In one typical case, a large ditch draining a rural area of 99 ha and flowing partly through an urbanized part was causing some problems at springtime, when the water levels in the main river were too high. The solution, shown in Figure 1.6, was to build a large detention basin of $18400 \mathrm{~m}^{3}$ that would capture the entire runoff volume for a return period of $50 \mathrm{y}$. The basin simply fills by overflows when the downstream outlet (the dimensions of which having been established on the available residual capacity downstream) chokes. 


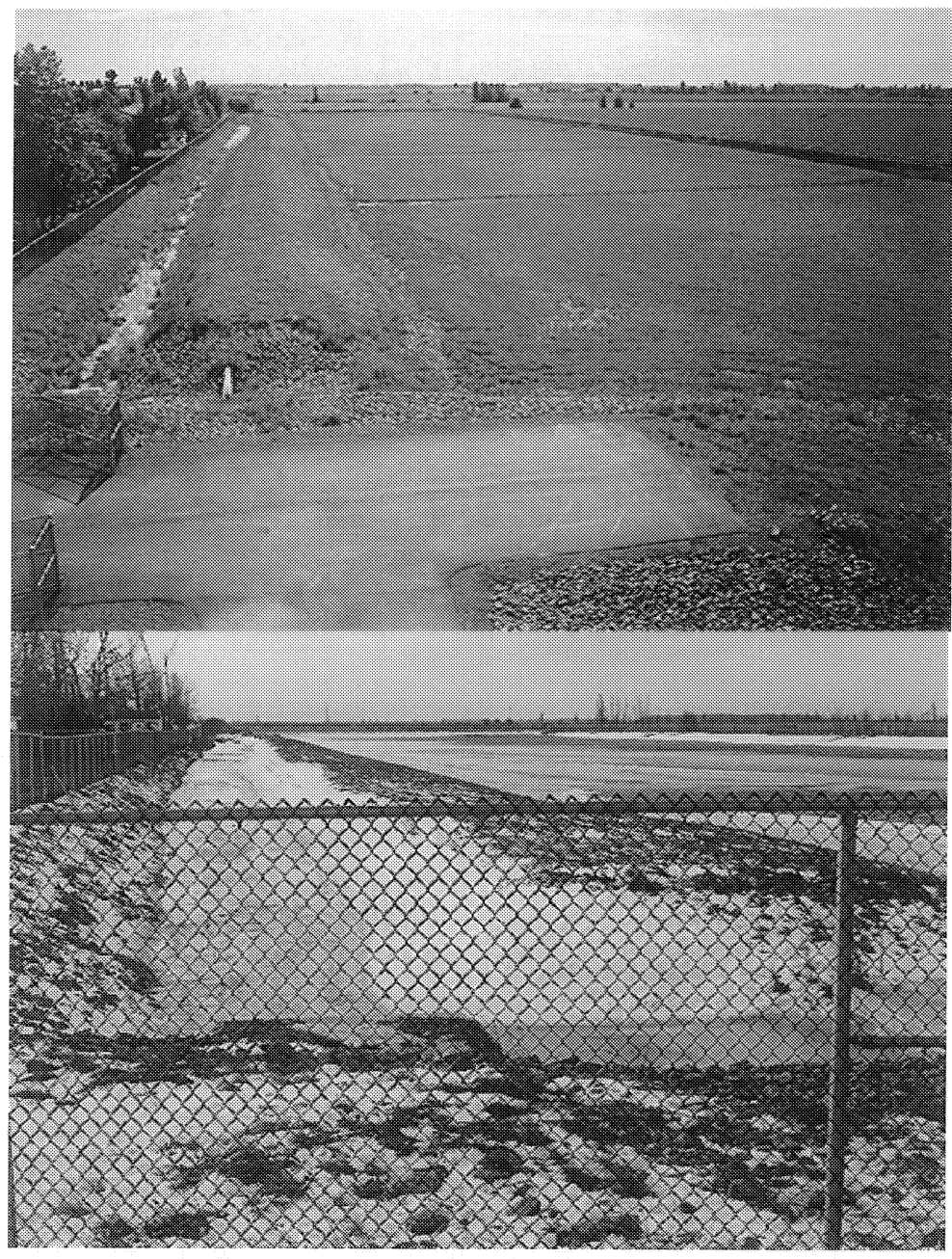

Figure 1.6 Retention basin on existing ditch connected to one of the main rivers, during summer (top photo) and at springtime (bottom).

For other areas, as it was established that the water contributing to flooding came from overflows of adjacent rivers, a dike was built around the entire existing developments, with a pumping station to remove runoff generated on the surface. The pumping station was designed to pump the runoff from a 100-y event with a 135-min duration (an observed event). 


\subsubsection{New Development}

For new developments in the fringe areas, a general concept was to use endof-pipe detention basins that could accumulate all the spring runoff from the local area when the water levels in the rivers were high and to control during summer the outflows to the 1/10 year discharge before the development (for erosion). Street storage and inlet restriction were included in the analysis, with detailed simulation using DDSWMM (Dual Drainage SWMM; Kassem, 1996) for runoff and the EXTRAN block of SWMM for pipe routing. Two areas were built with this approach, with basin dimensions of 6200 to $8300 \mathrm{~m}^{3}$. Figure 1.7 shows a plan view for one of the developed areas, and Figure 1.8 gives an overview of the detention basin. The drainage area of the urban drainage system

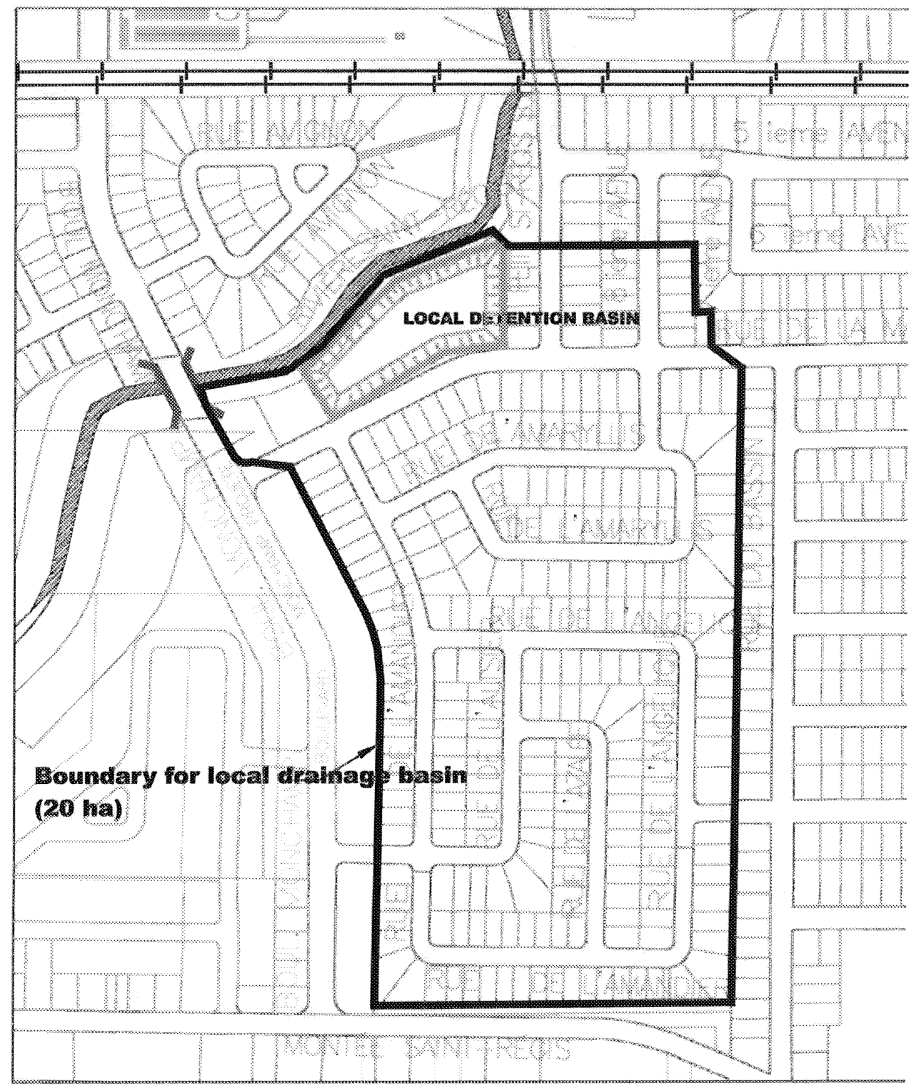

Figure 1.7 Plan view for a new development with end-of-pipe detention basin. 


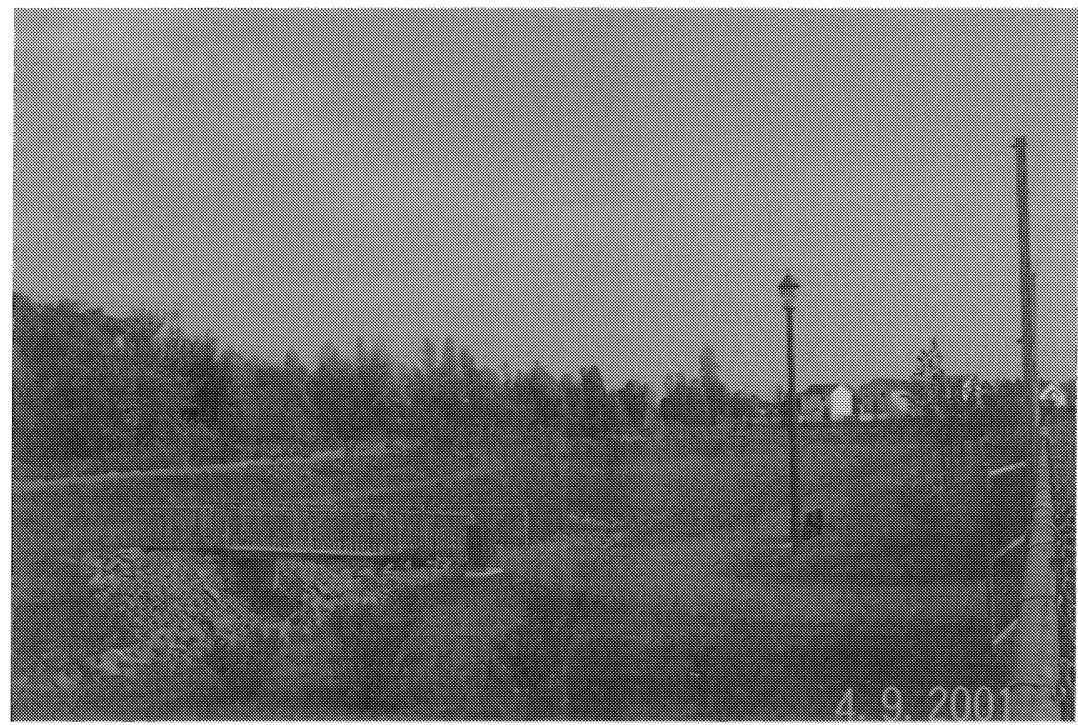

Figure 1.8 End-of-pipe detention basin for new development in the fringe area.

is in this case 20 ha, whereas the drainage area for the river at this point is about 3900 ha. A hybrid concept for new developments in the floodplain was therefore proposed and implemented, involving retention on the streets and detention ponds at outlet, taking into account the timing of floods in the rivers and the more rapid runoff processes at the local level.

\subsection{Conclusions}

A recent study (Forget et al., 2000) shows that, in the Province of Québec as in other regions of Canada, flood damage reduction measures based on designation and mapping of floodplains have had no impact on occupancy of the floodplain, have failed to reduce flood damages, and have not even halted increases in such damages. This is not very encouraging but illustrates the fact that these planning activities are complex and must take into account many parameters and global approaches. These approaches should use not only easier measures like flood mapping and floodplain delineation, but a large array of tools and diverse measures. 
Floodplain and stormwater management should ideally be considered and analyzed in an integrated way, as parts of the same global hydrological systems. This appears to be easier said than done, as these two planning activities have evolved as different tasks due to various historical and institutional reasons. Specific elements at their interface can however be used to develop optimal solutions and high (and uniform) level of service for the protection of life and property in both existing and newly developed areas.

\section{References}

Brooks, G.R. and Lawrence, D.E., 1998. Geomorphic Effects and Impacts from July 1996 Severe Flooding in The Saguenay Area, Québec. Natural Resources Canada, Geological Survey of Canada, Ottawa (http://sts.gsc.nrcan.gc.ca/page1/ geoh/saguenay/saguenay.htm).

Forget, S., Robert, B. and Rousselle, J. 2000. The Effectiveness of Flood Damage Reduction Measures in the Montreal Region. Office of Critical Infrastructure Protection and Emergency Preparedness, Government of Canada http://www.epcpcc.gc.ca/research/scie_tech/ef_floodmg/fdrp_mont/index_e.html

French and Associates, Ltd. 1998. Managing Floodplain Development Through the National Flood Insurance Program. Home study course prepared for FEMA (Federal Emergency Management Agency), United States.

Kassem, A. 1996. DDSWMM User Manual, AMK Associates, Ontario.

National Research Council of Canada , 1990. Hydrology of Floods in Canada: A Guide to Planning and Design. Ottawa, Ontario, Canada..

Rivard, G. 1998. Gestion des eaux pluviales: Concepts et applications (Stormwater Management: Concepts and applications), published by Alias Communication Design, Laval, Québec.

Rivard, G. and Dupuis, P. 1999. Criteria for surface on-site detention systems : a reality check, 8th International Conference on Urban Drainage, Sydney, Australia.

Walesh, S. 1989. Urban Surface Water Management. John Wiley and Sons, inc. New York.

Walesh, S.1999. Street Storage System for Control of Combined Sewer Surcharge. Contract No. 8C-R416-NTSX, Environmental Protection Agency (EPA), Edison, NJ. (http://www.epa.gov/ednnrmrl/repository/epa-600-r-00-065/).

Whipple, W., Grigg, N. S., Grizzard, T., Randall, C. W., Shubinski, R. P., Tucker, L. S. 1983. Stormwater Management in Urbanizing Areas. Prentice-Hall inc., Englewood Cliffs, New Jersey.

Wright, J.M. 2000. The Nation's Responses to Natural Disasters: A Historical Account. Report by the Association of State Floodplain Managers, Madison, WI. 
